\title{
Rapid screening for aluminum tolerance in maize (Zea mays L.)
}

\author{
Carlos Daniel Giaveno and José B. Miranda Filho
}

\begin{abstract}
A significant decrease in maize grain yield due to aluminum toxicity is considered to be one of the most important agricultural problems for tropical regions. Genetic improvement is a useful approach to increase maize yield in acid soils, but this requires a rapid and reliable method to discriminate between genotypes. In our work we investigated the feasibility of using hematoxylin staining (HS) to detect Al-tolerant plants at the seedling stage. The original population along with two populations obtained after one cycle of divergent selection were evaluated by net root growth (NRG) and HS after 7 days in nutrient solution. Results showed a negative correlation between NRG and HS in all populations, in which sensitive plants, characterized by low NRG, exhibited more intense staining than tolerant plants. These results indicate that $\mathrm{HS}$ is a useful procedure for selecting Al-tolerant maize seedlings.
\end{abstract}

\section{INTRODUCTION}

Aluminum toxicity is the major factor limiting plant growth in the acid soils that comprise large agricultural areas, principally in tropical and subtropical regions (Kochian, 1995). Several approaches have been suggested to increase grain yield in these soil types, closely related to root growth inhibition, which is considered to be the main effect of aluminum toxicity in higher plants. The degree of Al-induced root growth inhibition can be used to screen plants at the seedling stage for their relative aluminum sensitivity (Delhaize and Ryan, 1995; Kochian, 1995). There is considerable genetic variability in sensitivity in the major crops and the evaluation of root elongation in nutrient solution has been useful in developing Al-tolerant varieties (Delhaize et al., 1993; Pellet et al., 1995).

Higher plants make use of two main mechanisms to avoid the effects of Al toxicity, one being an exclusion mechanism, by which aluminum is prevented from crossing the plasmalemma and reaching the root cytoplasm by cell wall binding (Kochian, 1995), release of organic acids (especially citrate and malate) (Miyasaka et al., 1991; Delhaize et al., 1993; Pellet et al., 1995), and modification of the $\mathrm{pH}$ of the rhizosphere (Miyasaka et al., 1989). If aluminum does cross the plasmalemma, it is excluded by the ATPase pump located in the plasmalemma (Kochian, 1995). The other mechanism is an internal response, characterized by the production of specific proteins capable of forming complexes with toxic aluminum (Aniol, 1984; Basu et al., 1994).

Selection and breeding for aluminum tolerance are important approach for increasing grain yield in acid soils. Field trials have proved to be effective in selecting resistance but are very expensive and time-consuming. A rapid and reliable screening system is needed to discriminate sensitive and resistant genotypes. The selection of seed- lings in nutrient solution is a rapid screening method based on net root growth (NRG), developed to screen for aluminum tolerance in several crops. A rapid method using hematoxylin staining (HS) has been widely used for the direct visualization and localization of aluminum in root tissues (Rincón and Gonzales, 1992). It is a useful approach for macroscopically detecting aluminum accumulation in root tips by the formation of an intense blue coloration in the root tips of sensitive genotypes. This reaction occurs by the oxidation (in the presence of $\mathrm{NaIO}_{3}$ ) of hematoxylin to hematyn, which in the presence of aluminum produces nucleic acid coloration (Polle et al., 1978). The reaction of hematoxylin with aluminum-stressed roots has been used by several researchers in different crop species, such as wheat (Triticum aestivum L.) (Polle et al., 1978; Carver et al., 1988; Rincón and Gonzales, 1992; Tice et al., 1992), soybean (Glycine max Merrill) (Fonseca Jr., 1982; Fonseca Jr. et al., 1982; Spehar and Makita, 1994), the common bean (Phaseolus vulgaris L.) (Braccini et al., 1996) and maize (Zea mays L.) (Cançado, 1997).

Information about the utilization of hematoxylin stain in maize (Zea mays L.) is scarce and the work reported in this paper was undertaken to determine the effectiveness of this methodology for detecting Al-tolerant and -sensitive genotypes.

\section{MATERIAL AND METHODS}

Maize populations

Two thousand seedlings of tropical maize population SIKALQ were grown in a greenhouse for seven days in nutrient solution at $\mathrm{pH} 4.2$ and 5 ppm of aluminum as described by Furlani and Furlani (1988). The population SIKALQ is the result of an introgressive cross between 
the local population ESALQ-PB23A (50\% ESALQ PB2 and $50 \%$ ESALQ PB3; yellow endosperm) and the exotic variety SIKUANI ICA V-110 (Giaveno et al., 1998). Secondary roots of seedlings with similar length to the principal root were eliminated by hand and the length of the principal root measured to obtain the initial root length (IRL). After seven days, seedlings were removed from the nutrient solution and the final length of the principal root (FRL) of each plant was measured. NRG for individual plants was calculated as $\mathrm{NRG}=\mathrm{FRL}-\mathrm{IRL}$.

One cycle of divergent selection was completed by selecting the $10 \%$ most tolerant and $10 \%$ most sensitive seedlings. Selected seedlings of both groups were transplanted to the field and randomly crossed to obtain cycleI sub-populations, designated as CI-AT (Al-tolerant) and CIAS (Al-sensitive) as described by Giaveno et al. (1998).

\section{Growth measurements}

Treatments were the three maize populations described above, and the seedlings of each population were grown in a growth chamber for seven days at a constant temperature of $24^{\circ} \mathrm{C}$ and a 16-h light and 8-h dark photoperiod. Treatments were placed into four 3.5-liter buckets containing the same nutrient solution (Furlani and Furlani, 1988) in a completely randomized block design, in which the buckets were considered as blocks. At the end of this period an NRG value was calculated and the Pearson's coefficient of correlation with HS calculated. Values of NRG were analyzed by ANOVA and the means compared by the Duncan test.

\section{Hematoxylin staining of roots}

Preliminary studies using the tropical maize (Zea mays L.) populations CMS 36 (Al-tolerant) and BR 106 (Al-sensitive) were carried out in growth chambers to assess the best combination of time of exposure and $\mathrm{Al}$ concentration for HS (Giaveno and Miranda Filho, 1999).

After 24-h exposure to aluminum, seedlings were removed from the nutrient solution and stained for visual detection of aluminum using the method proposed by Polle et al. (1978), modified by Cançado (1997). Seedlings were placed in flasks containing deionized water and washed for $30 \mathrm{~min}$ in a horizontal shaker, and stained with hematoxylin solution $\left(2 \mathrm{~g} / \mathrm{l}\right.$ of hematoxylin and $0.02 \mathrm{~g} / \mathrm{l}$ of $\left.\mathrm{KIO}_{3}\right)$ for $15 \mathrm{~min}$. The seedlings were washed again for $20 \mathrm{~min}$ in deionized water to remove excess of stain.

Stained root tips were evaluated using a visual scale varying from 0 (highly tolerant) to 5 (highly sensitive). Values of HS were analyzed by ANOVA and the means compared by the Duncan test.

\section{RESULTS AND DISCUSSION}

In previous work we have shown that $24 \mathrm{~h}$ of $\mathrm{Al}$ exposure was sufficient to result in staining when the roots were subsequently treated with hematoxylin (Giaveno and Miranda Filho, 1999).

In the present work two parameters, NRG (Figure 1) and HS (Figure 2), were used to measure aluminum tolerance in maize seedlings, and both showed statistical differences among the populations (Table I). These results confirmed the effectiveness of the divergent selection for NRG.

The phenotypic correlation between NRG and HS for all populations showed a negative trend (Figure 3 ). It could be explained by the fact that susceptible seedlings have poor NRG as a consequence of high quantities of accumulated aluminum in the root cap and therefore, these genotypes show higher HS. On the other hand, tolerant seedlings have some mechanism to avoid aluminum toxicity, therefore they presenting higher NRG and low HS.

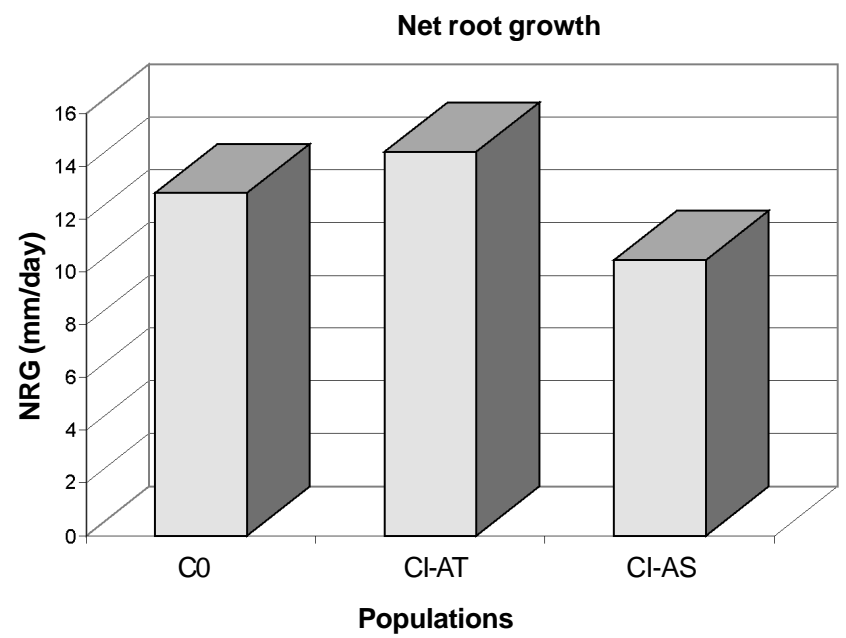

Figure 1 - Mean net root growth (NRG) values of the original (C0), Altolerant (CI-AT) and Al-susceptible (CI-AS) populations.

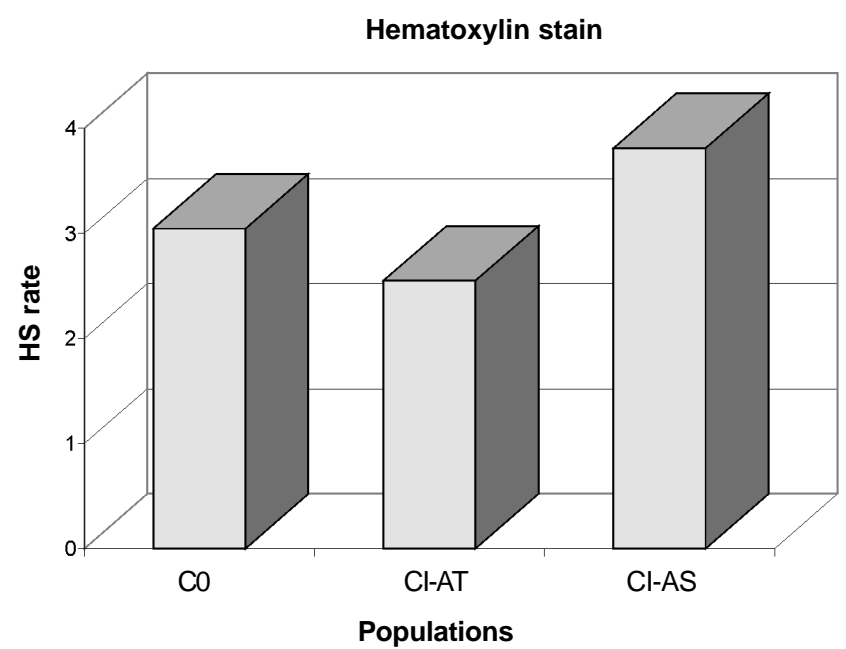

Figure 2 - Mean hematoxylin staining (HS) values of the original (C0), Altolerant (CI-AT) and Al-susceptible (CI-AS) populations. 
Table I - Observed means for net root growth (NRG) and hematoxylin staining (HS) for the original population ( $\mathrm{C} 0)$, and divergently selected populations (Al-tolerant (CI-AT) and Al-sensitive (and CI-AS)) along with the phenotypic correlation $\left(\mathrm{r}_{\mathrm{P}}\right)$ value between NRG and HS.

\begin{tabular}{|llll|}
\hline Treatment (populations) & NRG** & HS** & $\mathrm{r}_{\mathrm{P}}$ \\
\hline C0 & $12.99 \mathrm{~A}$ & $3.04 \mathrm{~B}$ & -0.77 \\
CI-AT & $14.55 \mathrm{~A}$ & $2.55 \mathrm{~B}$ & -0.79 \\
CI-AS & $10.45 \mathrm{~B}$ & $3.81 \mathrm{~A}$ & -0.75 \\
All plants & 12.65 & 3.30 & -0.82 \\
Coefficient of variation $(\%)$ & 18.57 & 22.55 & \\
\hline
\end{tabular}

**Significant differences among populations (C0, CI-AT, and CI-AS) at $\mathrm{P} \leq 0.01$. Duncan's test. Means with the same letter are not significantly different.

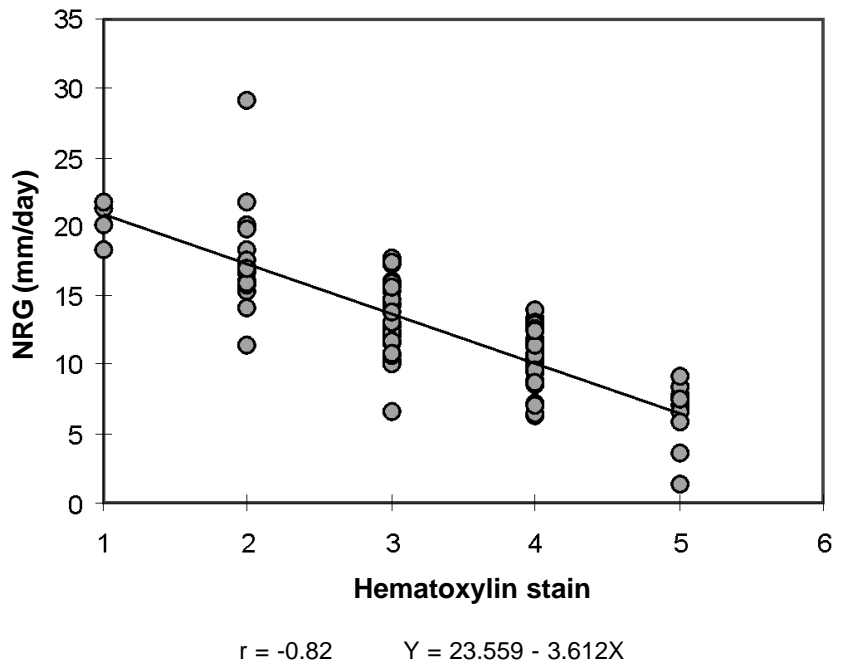

Figure 3 - Regression analysis of the data for all plants. NRG, Net root growth.

Our results show a possible selection effect on the phenotypic correlation value in both selected populations. In the tolerant population (CI-AT) there was a small increase in the phenotypic correlation coefficient $(-0.792)$ when compared to the original population $(-0.771)$. On the other hand a decrease in the correlation coefficient $(-0.757)$ was observed in the sensitive population. However, such trends cannot be necessarily assured in further selection cycles, and we can say that hematoxylin staining is highly negatively correlated trait with NRG in both the original and divergently selected populations.

Overall results are in agreement with other reports, such as that of Cançado (1997) who reported a correlation between HS and NRG of -0.693 and a relative root growth of -0.816 using $\mathrm{S}_{3}$ inbreed lines. Guevara et al. (1992) concluded that hematoxylin staining was a good criterion for discriminating between tolerant and sensitive maize seedlings. These results were partially confirmed by Ryan et al. (1993).

Our results lead us to conclude that hematoxylin staining is a suitable approach to the screening of maize seed- lings because it allows the rapid evaluation of a large number of genotypes without destroying the root apical meristem.

\section{ACKNOWLEDGMENTS}

The authors are grateful to Dr. Aikihiko Ando (Departamento de Genética ESALQ-USP) for technical assistance. Research and publication supported by FAPESP.

\section{RESUMO}

A importante diminuição nos rendimentos de milho causados pela toxidez produzida pelo alumínio é considerada um dos mais importantes problemas nas regiões tropicais. O melhoramento genético é uma metodologia útil para aumentar os rendimentos do milho em solos ácidos, requerendo um método rápido e seguro que permita diferenciar os diferentes genótipos. O objetivo deste trabalho foi avaliar a possibilidade de utilizar a técnica da coloração com hematoxilina (HS) na detecção de plântulas tolerantes ao alumínio. Duas populações obtidas de um ciclo de seleção divergente e a original, foram avaliadas depois de sete dias em solução nutritiva utilizando os parâmetros NRG (crescimento líquido da raiz principal) e HS. Os resultados apresentaram uma correlação negativa entre NRG e HS em todas as populações devido ao fato de que as plântulas suscetíveis, caracterizadas por um baixo NRG, apresentaram uma coloração mais intensa do que as tolerantes. Nossos resultados permitem concluir que a técnica de coloração com hematoxilina é um procedimento adequado para selecionar genótipos tolerantes ao alumínio em estado de plântula.

\section{REFERENCES}

Aniol, A. (1984). Induction of aluminum tolerance in wheat seedlings by low doses of aluminum in the nutrient solution. Plant Physiol. 75: 551-555.

Aniol, A.M. (1995). Physiological aspects of aluminum tolerance associated with the long arm of chromosome 2D of the wheat (Triticum aestivum L.) genome. Theor. Appl. Genet. 9: 510-516.

Basu, U., Basu, A. and Taylor, G.J. (1994). Differential exudation of polypeptides by roots of aluminum-resistant and aluminum-sensitive cultivars of Triticum aestivum L. in response to aluminum stress. Plant Physiol. 106: 151-158.

Braccini, M.C.L., Braccini, A.L., Martinez, H.E.P., Pereira, P.R.G. and Fontes, P.C.R. (1996). Técnicas de avaliação da toxidez do alumínio em plântulas de feijão (Phaseolus vulgaris L.) cultivadas em solução nutritiva. Rev. Ceres 43: 3-16.

Cançado, G.M.A. (1997). Aspectos bioquímicos e genéticos da tolerância ao alumínio tóxico em milho. Master's thesis, Universidade Federal de Viçosa, Viçosa, MG, Brazil.

Carver, B.F., Inskeep, W.P., Wilson, N.P. and Westerman, R.L. (1988). Seedling tolerance to aluminium toxicity in hard winter wheat germoplasm. Crop Sci. 28: 463-466.

Crawford, S.A. and Wilkens, S. (1998). Effect of aluminium on root elongation in two Australian perennial grasses. Aust. J. Plant Physiol. 25: $165-171$.

Delhaize, E. and Ryan, P.R. (1995). Aluminium toxicity and tolerance in plants. Plant Physiol. 107: 315-321.

Delhaize, E., Craig, S., Beaton, C.D., Bennet, R.J., Jagandish, V.C. and Randall, P.J. (1993). Aluminium tolerance in wheat (Triticum aestivum L.). I. Uptake and distribution of aluminium in root apices. Plant Physiol. 103: 685-693.

Fonseca Jr., N.S. (1982). Estudo da herança da tolerância ao alumínio em soja (Glycine max L. Merril) pelo método da hematoxilina. Master's 
thesis, Universidade Federal de Viçosa, Viçosa, MG, Brazil.

Fonseca Jr., N.S., Sediyama, M., Pereira, M.G., Yamada, M.M. and Tragnago, J.L. (1982). Método de deteção visual da sensibilidade ao alumínio em soja (Glycine max L. Merril). In: EMBRAPA: Anais do Seminário Nacional de Pesquisa de Soja 2: 678-685.

Furlani, A.M.C. and Furlani, P.R. (1988). Composição e pH de soluções nutritivas para estudos fisiológicos e seleção de plantas em condições nutricionais adversas. In: Boletim Técnico. IAC, Campinas, 121: 1-34.

Giaveno, C.D. and Miranda Filho, J.B. (1999). Visual detection of aluminum tolerance in maize (Zea mays L.). Genet. Mol. Biol. (Suppl.) 22: 677.

Giaveno, C.D., Miranda Filho, J.B. and Furlani, P.R. (1998). Tolerância ao alumínio em milho (Zea mays L.): seleção divergente em solução nutritiva. Genet. Mol. Biol. (Suppl.) 21: 242.

Guevara, P., Poschenrieder, C. and Barceló, J. (1992). Differential response of four maize (Zea mays L.) varieties to aluminium toxicity. Suelo Planta 2:713-721.

Kochian, L.V. (1995). Cellular mechanisms of aluminium resistance in plants. Annu. Rev. Plant Physiol. 46: 237-270.

Miyasaka, S.C., Kochian, L.V., Slaff, J.E. and Foy, C.D. (1989). Mechanism of aluminium tolerance in wheat. An investigation of genotypic differences in rhizosphere $\mathrm{pH}, \mathrm{K}^{+}$and $\mathrm{H}^{+}$transport, and root cell membranes potentials. Plant Physiol. 91: 1188-1196.
Miyasaka, S.C., Buta, J.G., Howell, R.K. and Foy, C.D. (1991). Mechanism of aluminium tolerance in snapbeans: Root exudation of citric acid. Plant Physiol. 96: 737-743.

Pellet, D.M., Grunes, D.L. and Kochian, L.V. (1995). Organic acid exudation as an aluminium-tolerance mechanism in maize (Zea mays L.). Planta 196: 788-795.

Polle, E., Konzak, C.F. and Kittrick, J.A. (1978). Visual detection of aluminium tolerance levels in wheat by hematoxylin staining of seedling roots. Crop Sci. 18: 823-827.

Rincón, M. and Gonzales, R.A. (1992). Aluminium partitioning in intact roots of aluminium-tolerant and aluminium-sensitive wheat (Triticum aestivum L.) cultivars. Plant Physiol. 99: 1021-1028.

Ryan, P.R., Ditomaso, J.M. and Kochian, L.V. (1993). Aluminium toxicity in roots: an investigation of spatial sensitivity and the role of the root cap. J. Exp. Bot. 44: 437-446.

Spehar, C.R. and Makita, M. (1994). Tolerância ao alumínio em plântulas de soja e sua utilização. Pesqui. Agropecu. Bras. 29: 1927-1932.

Tice, K.R., Parker, D.R. and DeMason, D.A. (1992). Operationally defined apoplastic and symplastic aluminium fractions in root tips of aluminiumintoxicated wheat. Plant Physiol. 100: 309-318.

(Received May 15, 2000) 